\title{
PENERAPAN MODEL PEMBELAJARAN KOOPERATIF DAN MODEL PEMBELAJARAN INDIVIDUAL DENGAN MENGGUNAKAN MINI LAB UNTUK MENINGKATKAN HASIL BELAJAR SMA SWASTA MEDAN
}

\author{
Hotma Tiolina Siregar
}

Surel: tiolinahotma@gmail.com

\begin{abstract}
This researc was aimed to investigate the differences between aplication of cooperative learning model and individual model using Mini Lab in biology class withs the topic reproduction system in private schools in Medan. The metodology that using in this research is experimental method with application of cooperative learning model at class XI-A SMA YPI and at class XI-A SMA AL-washliyah, then at class XI-B SMA YPI and at class XI-B SMA ALwashliyah using individual model. From the data analysa showed the mean of biology test with appliction of cooperative learning model is 7,61 and standart deviation is 0,34, Meanwhile the mean of biology test with aplication of individual learning model is 6,09 and standart deviation is 0,34. Then hypotheses test with $t$ test show hitung $>t$ table, then ho is rejected and alternatife is excepted.
\end{abstract}

Keywords: Cooperative Learning, Model, Individual

\section{PENDAHULUAN}

Kegiatan

praktikum

merupakan bagian penting dalam menunjang mata pelajaran IPA di SMA. Oleh sebab itu, diharapkan kepada guru agar melakukan kegiatan praktikum setelah memberikan teori pada mata pelajaran IPA, yang melibatkan aktivitas siswa, baik aktivitas fisik maupun mental emosional siswa. Kegiatan praktikum merupakan kegiatan yang dapat dilakukan diluar kelas, didalam kelas dan di laboratorium, namun kenyataannya masih banyak sekolah-sekolah swasta yang tidak memiliki fasilitas laboratorium untuk menunjang kegiatan belajar mengajar disekolah, sehingga sekolah tersebut tidak melakukan kegiatan praktikum kepada siswa.
(Dahar R.W.1989) Mini lab adalah kegiatan praktikum yang dilakukan didalam kelas dengan peralatan yang minimum dapat melakukan kegiatan praktikum untuk menunjang kegiatan teori yang telah diperoleh oleh siswa sebelumnya. Kegiatan praktikum yang seharusnya dilakukan di laboratorium khusus, maka dengan mini lab kegiatan praktikum dilakukan didalam kelas bagi sekolah-sekolah yang tidak memiliki fasilitas laboratorium bagi siswanya. Selama berlangsungnya kegiatan mini lab di kelas terjalin suatu interaksi sosial antara guru dan siswa, siswa dengan siswa yang juga merupakan jaringan komunikasi, sehingga terbentuk masyarakat kelas antara siswa dengan guru.

Mini lab memberikan siswa kesempatan untuk menyelidiki dan 
menentukan dengan bekerja dalam kelompok atau bekerja individual. Model pembelajaran kooperative suatu pendekatan belajar dengan cara siswa belajar dalam sekelompok kecil dengan tingkatan kemampuan berbeda dalam melakukan kegiatan praktikum mini lab, maka mini lab dapat dilakukan dengan model pembelajaran kooperatif dimana siswa bekerja dalam kelompok yang terdiri atas 4 - 5 siswa yang saling kerjasama dalam melakukan kegiatan mini lab, model pembelajaran individual merupakan suatu sistem yang disesuaikan dengan keadaan perseorangan, meliputi antara lain kemampuan dan kecepatan belajar dalam melakukan kegiatan praktikum dengan menggunakan mini lab.

\section{METODE PENELITIAN}

Penelitian adalah metode eksperimen, metode eksperimen diamati dalam bentuk observasi. Berdasarkan jenisnya, maka penelitian ini termaksud kedalam metode eksperimen semu. Variabel penelitian ini terdiri atas : 1 . Variabel terikat, yakni hasil belajar dan social skill pokok bahasan sistem reproduksi tumbuhan. 2. Variabel bebas, yakni model pembelajaran kooperatif dan model pembelajaran individual.

Populasi dari penelitian ini adalah seluruh siswa SMA Kelas XI yaitu SMA Swasta YPI dan SMA Swasta AL-Waslyah yang terdiri atas: 2 kelas siswa SMA Swasta YPI yang berjumlah 80 siswa dan 2 kelas siswa SMA Swasta AL-Waslyah yang berjumlah 80 siswa, jadi keseluruhan populasi berjumlah 160 siswa, sedangkan Sampel penelitian ini adalah sebanyak 80 siswa yang terdiri dari 40 siswa SMA Swasta YPI kelas XI dan 40 siswa SMA Swasta AL-waslyah kelas XI.

Adapun lembar observasi dalam penelitian ini adalah : 1) Lembar observasi aktivitas guru dan siswa dalam pembelajaran, 2)Lembar observasi keterampilan kooperatif dan individual siswa, 3) Perangkat dan hasil belajar. Dalam penelitian metodologi yang digunakan, yakni metode eksperimen, penelitian eksperimen ini dilakukan dalam tiga tahap, yakni tes awal, kegiatan pembelajaran kooperatif dan individual dan dilanjutkan tes akhir.

\section{HASIL PENELITIAN DAN PEMBAHASAN}

Deskripsi data Penelitian

(1). Hasil Belajar Biologi Kelas XIA SMA Swasta YPI dengan Pembelajaran Kooperatif, berdasarkan data yang diperoleh dari hasil penelitian dengan jumlah subjek 20 orang diperoleh nilai tertinggi 8,6 dan nilai terendah 6,9 dengan rata-rata nilai $(\mathrm{M})=7,89$ dan standart deviasi (SD) $=0,54$. (2). Hasil Belajar Biologi Kelas XI-B SMA Swasta YPI dengan Pembelajaran Individual, berdasarkan data yang diperoleh dari hasil penelitian dengan jumlah subjek 20 orang diperoleh nilai tertinggi 66 dan nilai terendah 5,4 
dengan rata-rata nilai $(\mathrm{M})=6,13$ dan standart deviasi (SD) $=0,27$. (3). Hasil Belajar Biologi Kelas XI-A SMA Swasta AL-Waslyah dengan Pembelajaran Kooperatif, berdasarkan data yang diperoleh dari hasil penelitian dengan jumlah subjek 20 orang diperoleh nilai tertinggi 8 dan nilai terendah 6,9 dengan rata-rata nilai $(\mathrm{M})=7,33$ dan standart deviasi (SD) $=0,33$. (4). Hasil Belajar Biologi Kelas XI-B SMA Swasta AL-Waslyah dengan Pembelajaran Individual, berdasarkan data yang diperoleh dari hasil penelitian dengan jumlah subjek 20 orang diperoleh nilai tertinggi 6,9 dan nilai terendah 5,4 dengan rata-rata nilai $(\mathrm{M})=6,06$ dan standart deviasi (SD) $=0,41$. (5). Hasil Observasi Keterampilan Kooperatif Siswa Kelas XI-A SMA Swasta YPI, berdasarkan data yang diperoleh dari hasil penelitian dengan jumlah subjek 20 orang diperoleh nilai tertinggi 9,7 dan nilai terendah 6,3 dengan rata-rata nilai $(\mathrm{M})=7,98$ dan standart deviasi (SD) $=$ 1,03. (6). Hasil Observasi Keterampilan Individual Siswa Kelas XI-B SMA Swasta YPI, berdasarkan data yang diperoleh dari hasil penelitian dengan jumlah subjek 20 orang diperoleh nilai tertinggi 6,9 dan nilai terendah 5,4 dengan ratarata nilai $(\mathrm{M})=6,19$ dan standart deviasi $(\mathrm{SD})=0,24$. (7). Hasil Observasi Keterampilan Kooperatif Siswa Kelas XI-A SMA ALWaslyah, berdasarkan data yang diperoleh dari hasil penelitian dengan jumlah subjek 20 orang diperoleh nilai tertinggi 9,2 dan nilai terendah 7,9 dengan rata-rata nilai $(\mathrm{M})=8,6$ dan standart deviasi (SD) $=0,45$. (8). Hasil Observasi Keterampilan Kooperatif Siswa Kelas XI-B SMA AL-Waslyah , berdasarkan data yang diperoleh dari hasil penelitian dengan jumlah subjek 20 orang diperoleh nilai tertinggi 7 dan nilai terendah 5,7 dengan rata-rata nilai $(M)=6,2$ dan standart deviasi $(\mathrm{SD})=0,33$.

Pengujian Persyaratan Analisis

Dalam pengujian analisis statistik untuk menguji hipotesis, maka dilakukan uji normalitas dan homogenitas. (1). Uji normalitas bertujuan untuk mengetahui normal tidaknya data tiap variabel penelitian, untuk menguji normalitas data digunakan uji liliefors. Uji normalitas diperoleh L0 $<$ L1 sehingga demikian dapat disimpulkan bahwa data setiap variabel penelitian adalah berdistribusi normal. (2). Uji homogenitas data yang digunakan uji stastiktik.

Pengujian Hipotesis

(a) pengujian hipotesis data pre-test, terdapat harga t hitung 1,448 dan bila dibandingkan dengan $\mathrm{t}$ tabel $=1,698$, maka t hitung < t tabel, sehingga Ho diterima dan dapat disimpulkan bahwa "tidak terdapat perbedaan hasil belajar siswa sebelum menerapkan model pembelajaran. (b) pengujian hipotesis data post-test, terdapat harga $\mathrm{t}$ hitung 34,031 dan bila dibandingkan dengan $\mathrm{t}$ tabel $=$ 
1,698, maka t hitung > t tabel, maka Ho ditolak dan $\mathrm{Ha}$ diterima. Sehingga dapat disimpulkan bahwa "terdapat perbedaan yang signifikan hasil belajar kooperatif dan individual dengan menggunakan mini lab”. Untuk mengetahui adanya pengaruh keterampilan siswa terhadap hasil belajar biologi digunakan rumus kolerasi dengan kriteria penerimaan jika $r$ hitung $>r$ tabel pada taraf nyata $=0,05$, maka dapat dikatakan ada pengaruh. Untuk semua data di peroleh rhitung > rtabel, sehingga dapat disimpulkan terdapat hubungan yang signifikan antara keterampilan (sosial skill) siswa dengan hasil belajar biologi.

\section{Temuan Penelitian}

Berdasarkan analisis data dikemukakan penemuan sebagai berikut: (1) dari pengolahan data pretes dan data post-tes diketahui bahwa sampel distribusi normal. (2) dari pengolahan data pre-tes diketahuiada perbedaan hasil belajar sebelum diterapkan model pembelajran. (3) nilai rata-rata hasil belajar dengan model pembelajaran kooperatif sebesar 7,61 dengan standar deviasi sebesar 0,34, sedangkan nilai ratarata hasil belajar dengan model pembelajaran individual sebesar 6,09 dengan standar deviasi sebesar 0,34. (4) terdapat perbedaan yang signifikan hasil belajar dengan menerapkan model pembelajaran kooperatif dan individual dengan menggunakan mini lab. (5) terjadi perbedaan tersebut dikarenakan pada siswa yang mendapat pembelajaran kooperatif lebih aktif, proses belajar siswa terlibat secara intelektual, betul-betul berperan dan berpartisipasi aktif didalam melakukan kegiatan belajar. (6) keterampilan kooperatif dan individual siswa dapat mempengaruhi hasil belajar siswa, dalam arti semakin tinggi keterampilan siswa maka hasil belajarnya akan semakin baik.

Dilihat dari hasil penelitian, hasil belajar biologi siswa dengan penerapan model pembelajaran kooperatif lebih tinggi dibandingkan dengan model pembelajaran individual. Hal ini dapat dilihat dari nilai rata-rata siswa yang diterapkan model pembelajaran kooperatif sebesar 7,61 dengan standar deviasi sebesar 0,34 , sedangkan nilai ratarata hasil belajar dengan model individual sebesar 6,09 dengan atandar deviasi sebesar 0,34. Adanya perbedaan itu, karena penerapan model pembelajaran kooperatif memberikan kesempatan kepada siswa untuk terlibat secara aktif dalam proses berfikir dan kegiatan belajarnya dikelas. Siswa dalam kelompok kecil dengan tingkat kemampuan yang berbeda, saling membantu untuk memahami satu pelajran, meriksa dan memperbaiki jawaban teman, serta kegiatan lainnya dengan tujuan mencapai hasil belajar tinggi.

\section{SIMPULAN}

Simpulan hasil penelitian ini adalah: (1) ada perbedaan hasil belajar biologi kelompok siswa yang 
belajar dengan menerapkan model pembelajaran kooperatif sebesar 7,61 dengan standar deviasi sebesar 0,34 dan nilai rata-rata hasil belajar dengan model pembelajaran individual sebesar 6,09 dengan standar deviasi sebesar 0,34. (2) hasil belajar biologi siswa yang belajar dengan menerapkan model pembelajaran kooperatif lebih baik daripada hasil belajar biologi siswa yang menggunakan model pembelajaran dindividual. (3) keterampilan (social skill) siswa dapat mempengaruhi hasil belajar biologi siswa.

Untuk menghasilkan siswa dengan prestasi yang baik, para guru dituntut menguasai berbagai model pembelajaran yang akan digunakan dalam kegiatan belajar mengajar, dengan menerapkan model pembelajaran kooperatif diharapkan timbul suatu komunikasi aktif antara siswa dalam diskusi, dan dianjurkan kepada guru yang mengajar agar tetap membimbing dan mengarahkan siswa dalam proses pembelajaran berlangsung. Dalam pembelajaran bidang studi biologi, akan tercapai prestasi yang lebih baik apabila sekolah memiliki fasilitas laboratorium yang mendukung untuk mengadakan praktikum, serta guru dapat menerapkan model-model pembelajaran yang sesuai dengan materi yang dipelajarinya.

\section{DAFTAR RUJUKAN}

Arikunto, Suharsimi. 2006. Dasardasar evaluasi Pendidikan. Jakarta: Bumi Aksara.
Dahar, R. W. 1989. Teori-teori belajar. Jakarta : Erlangga.

Djamarah, S.B. Zain A. 2002. Strategi Belajar Mengajar. Jakarta: Rineka Cipta.

Faisal, S. 1992. Metodologi Pendidikan. Surabaya : Usaha Nasional

Hamalik, O. 2002. Proses Belajar Mengajar. Jakarta Bumi Aksara.

Irianto, A. 2004. Statistik Konsep Dasar dan Aplikasinya. Jakarta: Prenada Media.

Jalaluddin. Idi A. 1997. Filsafat Pendidikan. Jakarta: Gaya Media Pertama.

Karli. H. Yuliartiningsih M. 2002. Implementasi Kurikulum Berbasis Kompetisi. Bandung: Bima Media Informasi.

Lie. A. 2004. Kooperatife Learning. Jakarta : Grasindo

Mulyasa. 2002. Kurikulum Berbasis Kompetisi. Bandung: Remaja Rosdakarya.

Mudjijo. 1990. Belajar Mudah Penelitian. Bandung: Bumi Aksara.

Sudjana. 1992. Metode Statistika. Bandung: Tarsito.

Sudijono. A. 2004. Statistik Pendidikan. Jakarta: Raja Grafindo.

Sudjadi. B. 2005. Biologi. Surabaya : Yudistira.

Sukardi. 2004. Metodologi Penelitian Pendidikan. Jakarta: Bumi Aksara. 
